\title{
VISUALISASI INFORMASI WEBSITE INTERNATIONAL CONFERENCE BERDASARKAN WEB-QUALITY FRAMEWORK
}

\author{
1, ${ }^{*}$ Lalu Arfi Maulana Pangistu, ${ }^{2}$ Ahmad Azhari, ${ }^{3}$ Agus Aktawan \\ ${ }^{1}$ Teknik Informatika, Universitas Ahmad Dahlan, Yogyakarta, Indonesia \\ 2Teknik Informatika, Universitas Ahmad Dahlan, Yogyakarta, Indonesia \\ 3Teknik Kimia, Universitas Ahmad Dahlan, Yogyakarta, Indonesia \\ e-mail: laluarfi17@gmail.com, ahmad.azhari@tif.uad.ac.id, agus.aktawan@che.uad.ac.id \\ *) correspondence email
}

\begin{abstract}
Abstrak
Konferensi merupakan pertemuan yang bertujuan untuk bertukar pendapat mengenai suatu masalah yang dihadapi bersama. Dengan adanya perkembangan teknologi membuat manusia berfikir untuk dapat bekerja lebih efektif dan efisien. Salah satunya yaitu membuat sistem konvensional menjadi sistem yang terkomputerisasi. Dengan memanfaatkan fasilitas website yang terhubung ke internet, pihak penyelenggara konferensi dapat lebih efektif untuk melakukan penyebaran informasi, registrasi, submisi, dan kegiatan lain yang berhubungan dengan konferensi. Pentingnya pengukuran kualitas pada website menjadi tolak ukur dalam meningkatkan kinerja sesuai dengan visi dan misi dari penerapan website. Pada penelitian ini, penulis merancang sistem informasi pada konferensi internasional berbasis website. Metodologi pengembangan website yang digunakan dalam penelitian ini adalah Software Development Life Cycle (SDLC). Metode pengujian kualitas website menggunakan 4 metode pengujian, diantaranya Alpha Test, SUS, UAT, dan UEQ. Sistem ini menghasilkan sistem informasi konferensi internasional berbasis website yang bekerja dengan baik dengan hasil pengujian alpha test sebesar 92\%, menampilkan informasi yang sesuai dengan hasil pengujian SUS sebesar 73\%, dapat diterima masyarakat dan layak ditunjukkan dari hasil pengujian UAT sebesar 75\%, dan pengujian User Experience (UX) mendapatkan penilaian yang masuk ke dalam kategori "baik" dari hasil pengujian UEQ.
\end{abstract}

Kata Kunci: Website, SDLC, Alpha Test, SUS, UAT, UEQ, Sistem Informasi

\section{PENDAHULUAN}

Secara online kita dapat menggunakan website sebagai wadah untuk mendapatkan dan menyebarkan informasi ke masyarakat luas [1]. Website merupakan produk multimedia interaktif berupa media informasi berbasis jaringan komputer yang dapat diakses dimana saja dan kapan saja dengan biaya yang relatif murah. Dengan adanya website, instansi akan dengan mudah mempromosikan dan memberitahukan kepada masyarakat luas tentang profil, kegiatan, informasi, dan halhal lain yang berkaitan dengan instansi tersebut [2]-[4]. Selain itu, website memungkinkan instansi untuk memperoleh kemudahan dalam pengorganisasian file.

Penggunaan multimedia interaktif digunakan untuk menyajikan dan menggabungkan teks, grafik, audio dan video, dengan tautan dan alat yang memungkinkan pengguna menavigasi, berinteraksi, membuat dan berkomunikasi [5].

Teknologi informasi dan komunikasi (TIK) berkembang dengan sangat pesat, merambat ke berbagai sektor dengan kecepatan yang sangat mengagumkan. Terdapat klasifikasi pemanfaatan TIK ke dalam tiga jenis, yaitu pertama, TIK sebagai media (alat bantu) pendidikan yaitu hanya sebagai pelengkap untuk memperjelas uraian uraian yang disampaikan. Kedua, TIK sebagai sumber yakni sebagai sumber informasi dan mencari informasi. Ketiga, TIK sebagai sistem pembelajaran. Pada bidang pendidikan 
terutama di kalangan Universitas, teknologi informasi sangat membantu mahasiswa dalam mencari sumber belajar. Sebagai contoh dengan memanfaatkan internet seorang mahasiswa dapat belajar menggunakan e-learning, e-library, e-research, dan $e$ conference. Salah satu produk multimedia interaktif yang sangat berpengaruh sekarang ini adalah penggunaan aplikasi web atau sering dikenal dengan sebutan website. Instruksi pembelajaran berbasis website dalam e-learning dapat menjadi media yang efektif untuk meningkatkan kemampuan siswa apabila didesain sesuai dengan ketentuan pembelajaran berbasis website [6].

Seminar dan konferensi merupakan salah satu kegiatan yang sering dilakukan oleh suatu institut atau lembaga pendidikan [7]. Contoh penerapan e-conference yaitu dengan diselenggarakannya International Conference on Engineering and Applied Technology (ICEAT) oleh Forum Grup Diskusi Teknologi Perguruan Tinggi Muhammadiyah (FGDT-PTM). FGDT-PTM adalah sebuah forum bagi para dosen dan peneliti untuk berdiskusi, sharing pengetahuan tentang manajemen perguruan tinggi, pemanfaatan teknologi ataupun hasil penelitian. ICEAT merupakan konferensi internasional yang diselenggarakan oleh FGDT-PTM sejak tahun 2017, bertempat di Mataram, Lombok, pada tanggal 29 - 30 November 2017. Dilanjutkan pada tahun 2018 ICEAT diselenggarakan di Aceh, NAD, pada tanggal 9 - 10 Oktober 2018. Kemudian pada tahun 2019 ICEAT diselenggarakan di Sorong, Papua, pada tanggal 30 Oktober - 1 November 2019 dan pada tahun 2020 akan diselenggarakan di Magelang, Jawa Tengah.

Pentingnya pengukuran kualitas produk multimedia terdapat pada perancangan materi multimedia yang baik sehingga memiliki dampak positif, dapat meningkatkan kinerja yang lebih baik dan menyenangkan bagi peserta didik. Penggunaan produk multimedia perlu disertai informasi terkait kualitas produk. Dengan mengadopsi konten yang berkualitas maka dapat menghindarkan hasil produk yang buruk [4][7].

Saat ini ICEAT sudah memiliki website, tetapi website yang dimiliki hanya memiliki konten untuk ICEAT yang sedang diselenggarakan dalam waktu dekat, dikarenakan host yang berbeda tiap tahun berdasarkan penunjukan di FGDT-PTM. Oleh karena itu, melalui penelitian ini penulis merancang website yang menampung informasi, galeri, kontak, dan hal-hal yang terkait dengan pelaksaan ICEAT di tahun sebelumnya yang dimulai pada tahun 2017, ICEAT yang sedang berlangsung maupun ICEAT yang akan datang dengan menerapkan penilaian kualitatif berdasarkan webquality framework [5].

\section{METODE}

\section{A. METODE PENGAMBILAN DATA}

Untuk menghasilkan visual dashboard yang baik, kita juga perlu mengumpulkan data terkait pengetahuan yang ingin kita capai melalui dashboard [3][4]. Ada enam langkah utama yang dilakukan dalam penelitian ini:

1. Metode wawancara, yaitu mendapatkan informasi dengan cara mengajukan pertanyaan secara langsung kepda client.

2. Metode observasi, yaitu teknik pengumpulan data dengan melakukan pengamatan secara langsung dan bergabung untuk membuat website dengan kepanitaan. 
3. Alpha Test, System Usability Scale (SUS) test, User Acceptance Test (UAT), User Experience Questionnaire (UEQ).

Tabel 1 menggambarkan proses yang dilakukan selama penelitian dengan memetakan setiap tahap dengan metode dan setiap hasil kategorisasi data.

Tabel 1. Metode Pengembangan

\begin{tabular}{lccccc}
\hline & $\begin{array}{c}\text { Pre- } \\
\text { Requirement }\end{array}$ & $\begin{array}{c}\text { Pengujian } \\
\mathbf{1}\end{array}$ & $\begin{array}{c}\text { Pengujian } \\
\mathbf{3}\end{array}$ & $\begin{array}{c}\text { Pengujian } \\
\mathbf{3}\end{array}$ & Pengujian 4 \\
\hline Metode & $\begin{array}{c}\text { Survey, } \\
\text { interview } \\
\text { informal }\end{array}$ & $\begin{array}{c}\text { Kuesioner, } \\
\text { Alpha Test }\end{array}$ & $\begin{array}{c}\text { Kuesioner, } \\
\text { System } \\
\text { Usability } \\
\text { Scale }\end{array}$ & $\begin{array}{c}\text { Kuesioner, } \\
\text { User } \\
\text { Acceptance } \\
\text { Test }\end{array}$ & $\begin{array}{c}\text { Kuesioner, } \\
\text { User } \\
\text { Experience } \\
\text { Questionnaire }\end{array}$ \\
\hline $\begin{array}{l}\text { Jumlah } \\
\text { Peserta }\end{array}$ & 1 & 17 & 17 & 20 & 17 \\
\hline $\begin{array}{l}\text { Jenis Data } \\
\text { Yang } \\
\text { Diperoleh }\end{array}$ & Kualitatif & Kuantitatif & Kuantitatif & Kuantitatif & Kuantitatif \\
\hline
\end{tabular}

\section{B. METODE PENGEMBANGAN SISTEM}

Pengembanan website ICEAT menggunakan metode System Development Life Cycle (SDLC). SDLC adalah proses pembuatan dan pengubahan sistem serta model dan metodologi yang digunakan untuk mengembangkan sistemsistem tersebut. SDLC berfungsi untuk menggambarkan tahapan - tahapan utama dan langkah - langkah dari setiap tahapan yang secara garis besar terbagi dalam lima kegiatan utama, yaitu: analisis, perancangan sistem, desain sistem, pengkodean, uji coba, implementasi, pemeliharaan sistem. Flowchart SDLC dapat dilihat pada Gambar 1 [8].

a. Analisis Sistem

Analisis sistem adalah penguraian dari suatu sistem yang utuh kedalam kegiatan-kegiatan komponennya, dengan maksud untuk mengidentifikasikan dan mengevaluasi permasalahan-permasalahan, kesempatan-kesempatan, hambatan-hambatan, yang terjadi dan kebutuhan-kebutuhan yang diharapkan sehingga dapat diusulkan perbaikan-perbaikannya.

b. Desain Sistem

Desain Sistem adalah persiapan rancang bangun implementasi yang menggambarkan bagaimana suatu sistem dibentuk yang berupa penggambaran, perencanaan dan pembuatan sketsa atau pengaturan dari beberapa elemen yang terpisah kedalam satu kesatuan yang utuh dan berfungsi, menyangkut di dalamnya konfigurasi komponen perangkat lunak dan perangkat keras dari suatu sistem. 


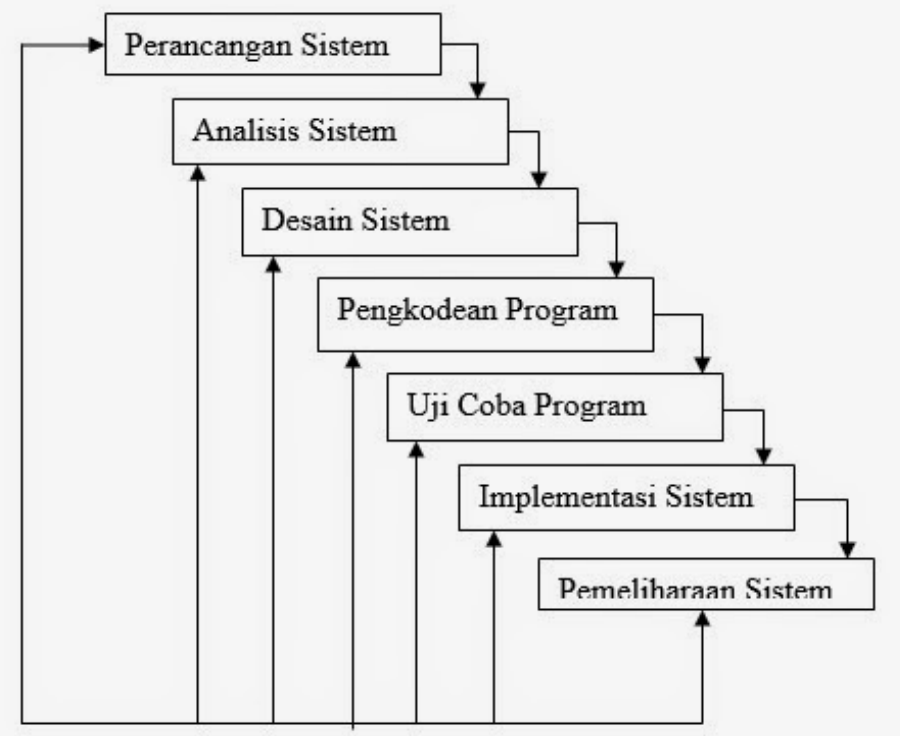

Gambar 1. Flowchart System Development Life Cycle

c. Pengkodean (Coding)

Menerjemahkan hasil proses perancangan menjadi sebuah bentuk program komputer yang dimengerti oleh mesin komputer.

d. Uji Coba Program

Uji coba software merupakan elemen yang kritis dari SQA (Software Quality Assurance) dan mempresentasikan tinjauan ulang yang menyeluruh terhadap spesifikasi, desain dan pengkodean. Uji coba mempresentasikan ketidak normalan yang terjadi pada pengembangan software. Selama definisi awal dan fase pembangunan, pengembangan berusaha untuk membangun software dari konsep yang abstrak sampai dengan implementasi yang memungkinkan.

e. Implementasi Sistem

Implementasi sistem adalah tahap penerapan sistem yang akan dilakukan jika sistem disetujui termasuk program yang telah dibuat pada tahap perancangan sistem agar siap untuk dioperasikan.

f. Pemeliharaan Sistem

Pemeliharaan sistem adalah suatu kombinasi dari berbagai tindakan yang dilakukan untuk menjaga suatu sistem dalam, atau memperbaikinya sampai, suatu kondisi yang bisa diterima.

\section{METODE PENGUJIAN}

Metode yang digunakan untuk pengujian sistem yaitu menggunakan metode Quality Framework yang bertujuan untuk menjadi kerangka standar Quality Framework yang dapat digunakan oleh pengguna dalam mengevaluasi website [5]. Adapun metode yang digunakan, yaitu metode Alpha Test, Software Usability Test (SUS), User Acceptance Test (UAT), dan User Experience Questionnaire (UEQ).

\section{Alpha Test}

Alpha Test adalah salah satu strategi pengujian perangkat lunak yang paling umum digunakan dalam pengembangan perangkat lunak, hal ini khusus digunakan oleh organisasi pengembangan produk dengan 
tujuan agar sistem yang dikembangkan terhindar dari cacat atau kegagalan penggunaan.

2. System Usability Scale (SUS)

Penelitian yang dilakukan Murein dkk (2017) menerapkan analisa kualitatif dengan menggunakan SUS untuk menunjukkan tingkat penerimaan dari hasil evaluasi kegiatan pembelajaran yang dilakukan pada Program Pendidikan Matematika Universitas Ahmad Dahlan. Hasil SUS yang diperoleh sebesar 75 dari nilai rata-rata semua peserta [3].

Usability dapat berarti bahwa sesuatu dapat digunakan dengan baik. Istilah ini digunakan untuk mengukur kualitas suatu sistem informasi, perangkat lunak maupun website, berkaitan dengan kemudahan dalam mempelajari dan menggunakan sistem sehingga mendorong pengguna untuk menggunakan sistem tersebut untuk membantu dalam menyelesaikan tugas [9]. System Usability Scale (SUS) merupakan kuesioner untuk mengukur persepsi kegunaan. Diciptakan oleh John Brooke pada tahun 1986 dan dahulu digunakan untuk melakukan evaluasi berbagai jenis produk ataupun layanan, termasuk di dalamnya hardware, software, perangkat mobile, website, dan aplikasi [10]. Pengukuran usability menggunakan SUS tidak memerlukan waktu yang lama [11].

3. User Acceptance Test (UAT)

User Acceptance Test (UAT) adalah suatu proses pengujian oleh pengguna yang dimaksudkan untuk menghasilkan dokumen yang dijadikan bukti bahwa sistem yang dikembangkan dapat diterima atau tidaknya oleh pengguna, apabila hasil pengujian sudah bisa diangap memenuhi kebutuhan dari pengguna maka aplikasi dapat diterapkan [12].

4. User Experience Questionnaire (UEQ)

User Experience (UX) merupakan faktor penting untuk menentukan suatu informasi sudah cukup memadai, penerimaan oleh penggunanya, atau belum. User Experience Questionnaire (UEQ) merupakan alat atau kuesioner yang mudah dan efisien untuk mengukur UX [13]. UEQ memberikan penilaian secara cepat terhadap pengalaman pengguna interaktif. Skala kuesioner dari UEQ dirancang untuk dapat menangani impresi dari pengalaman pengguna yang komprehensif. UEQ memiliki format kuesioner yang dapat mendukung respon user untuk segera mengutarakan perasaan, kesan, dan sikap yang muncul ketika user berinteraksi dengan suatu produk [14]. UEQ ini memudahkan kita untuk mengukur UX pada sebuah desain aplikasi. UEQ berisi 6 skala penilaian, yaitu:

a. Daya Tarik (Attractiveness): Apakah pengguna menyukai atau tidak menyukai produk?

b. Kejelasan (Perspicuity): Apakah mudah untuk mengenal produk? Apakah mudah untuk belajar bagaimana gunakan produknya?

c. Efisiensi (Efficiency): Bisakah pengguna menyelesaikan tugas mereka tanpa usaha yang sederhana?

d. Ketepatan (Dependability): Apakah pengguna merasa terkendali terhadap interaksi? 
e. Stimulasi (Stimulation): Apakah menarik dan memotivasi untuk menggunakan produk

f. Kebaruan (Novelty): Apakah produk itu inovatif dan kreatif? Apakah produk menangkap minat pengguna?

D. REKRUTMEN PESERTA

Objek peserta dipilih secara acak dan menghasilkan 17 orang peserta untuk melakukan pengujian alpha test, 17 orang peserta untuk pengujian SUS, 20 orang peserta untuk melakukan pengujian UAT, 17 orang peserta untuk melakukan pengujian UEQ.

\section{HASIL DAN PEMBAHASAN}

\section{Proses Bisnis}

Pengunjung atau calon peserta mengunjungi website 2020 4th International Conference on Engineering and Applied Technology untuk mencari informasi yang dibutuhkan seputar kegiatan yang akan dilaksanakan, kemudian calon peserta dapat melakukan register untuk ikut serta dalam kegiatan yang akan dilaksanakan. Alur dari proses bisnis dari website yang ada saat ini dapat dilihat pada Gambar 2 dan Gambar 3.

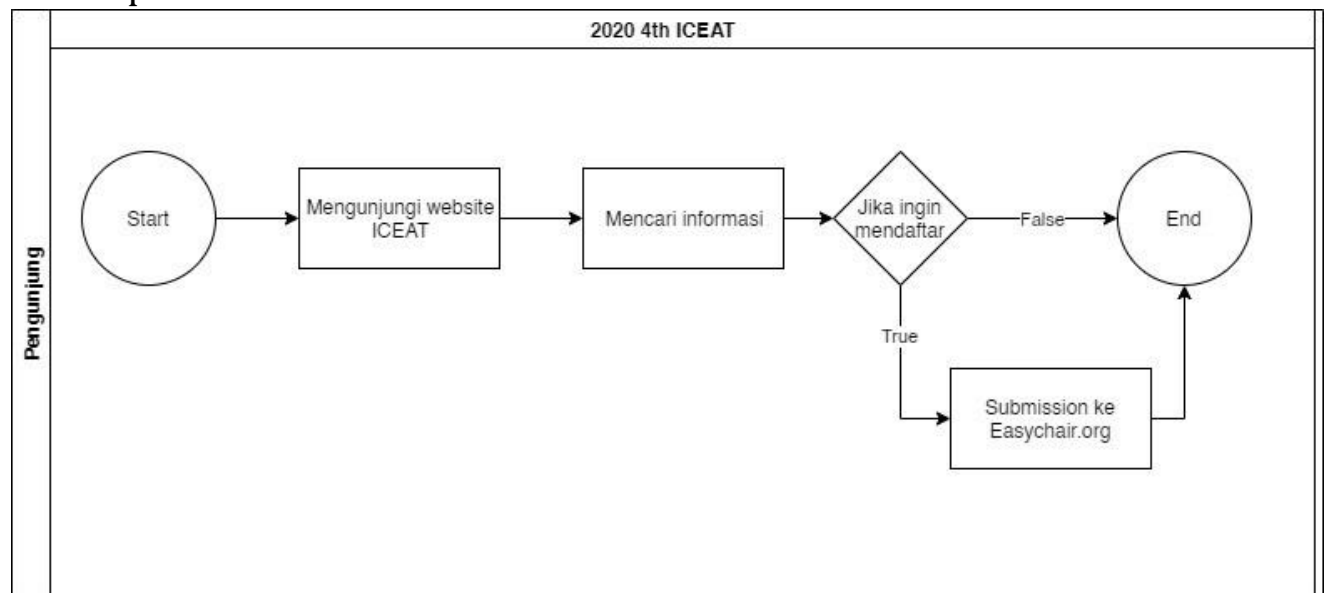

Gambar 2. Proses Bisnis Submission

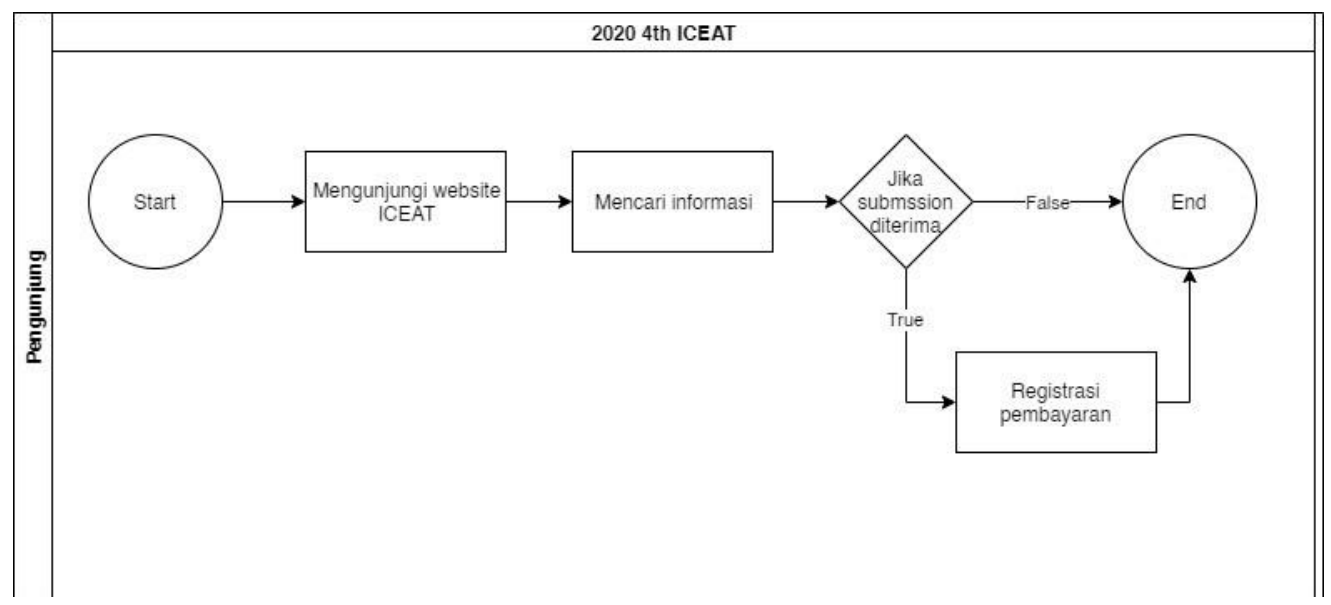

Gambar 3. Proses Bisnis Registrasi Pembayaran

Proses bisnis submission pada Gambar 2 dimulai dari start dimana pengunjung mulai mengunjungi website kemudian pengunjung mencari 
informasi tentang kegiatan yang akan diadakan setelah itu mendaftar jika berminat mengikuti kegiatan tersebut, ketika mendaftar pengunjung mengklik tombol submission yang sudah disediakan dan akan diarahkan ke website easychair.org, jika tidak ingin mendaftar langsung menuju proses end.

Proses bisnis registrasi pembayaran pada Gambar 3 dimulai dari start dimana pengunjung mengunjungi website kemudian pengunjung mencari informasi tentang registrasi pembayaran, jika submission diterima maka melakukan pembayaran jika tidak langsung menuju proses end.

\section{Implementasi Sistem}

Sistem informasi ICEAT dikembangkan menggunakan HTML, CSS, dan JavaScript.

a. Halaman Home

Pada halaman home terdapat menu navigasi di bagian atas website yaitu diantaranya yaitu home, about, news, keynote speakers, committees, venue, dan program. Pada halaman ini terdapat informasi tanggal, tempat diselenggarakan, submission, biaya pendaftaran, conference tracks, tanggal penting, galeri, kontak. Hasil implementasi halaman home dapat dilihat pada Gambar 4, Gambar 5, Gambar 6, dan Gambar 7.

b. Halaman News

Pada halaman news terdapat berita terbaru tentang kegiatan yang akan berlangsung. Hasil implementasi halaman news dapat dilihat pada Gambar 8.

c. Halaman Keynote Speakers

Pada halaman keynote speakers menamplikan informasi tentang pembicara yang akan mengisi rangkaian acara tersebut. Hasil implementasi halaman keynote speakers dapat dilihat pada Gambar 9.

d. Halaman Committees

Pada halaman committees menampilkan informasi nama - nama yang menjadi panitia dari acara yang akan dilaksanakan. Hasil implementasi halaman committees dapat dilihat pada Gambar 10.

e. Halaman Venue

Pada halaman venue menampilkan informasi dimana acara tersebut akan diselenggarakan. Hasil implementasi halaman venue dapat dilihat pada Gambar 11.

f. Halaman Program

Pada halaman program menampilkan informasi program apa saja yang ada pada acara tersebut. Hasil implementasi halaman program dapat dilihat pada Gambar 12.

g. Halaman Register

Pada halaman register menampilkan biaya pendaftaran dan form pendaftaran untuk acara yang akan diselenggarakan. Hasil implementasi halaman register dapat dilihat pada Gambar 13.

h. Halaman About

Pada halaman about menampilkan apa itu ICEAT dan sejak kapan ICEAT mulai diselenggarakan oleh AST-PTM. Rancangan sistem halaman about dapat dilihat pada Gambar 14. 


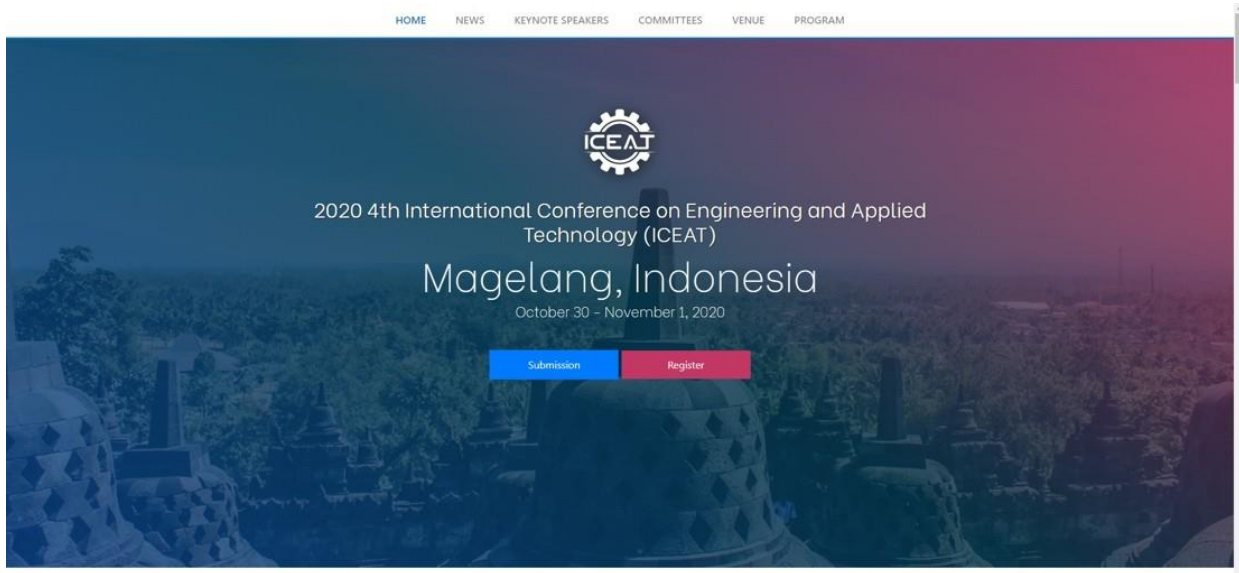

Gambar 4. Implementasi Halaman Home

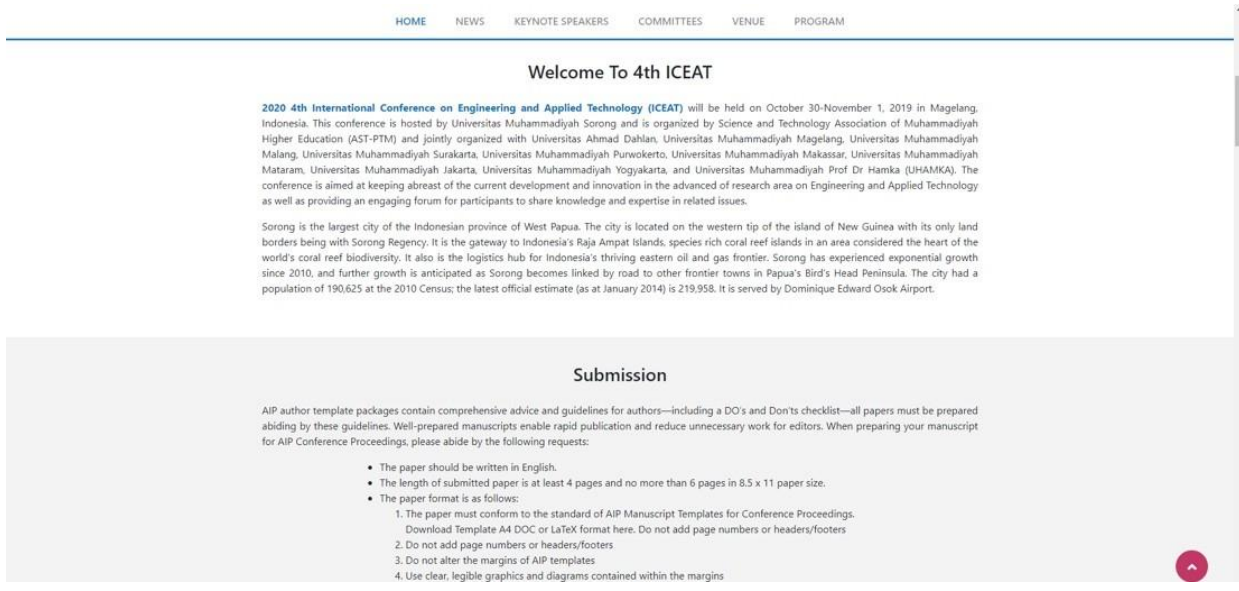

Gambar 5. Implementasi Halaman Home

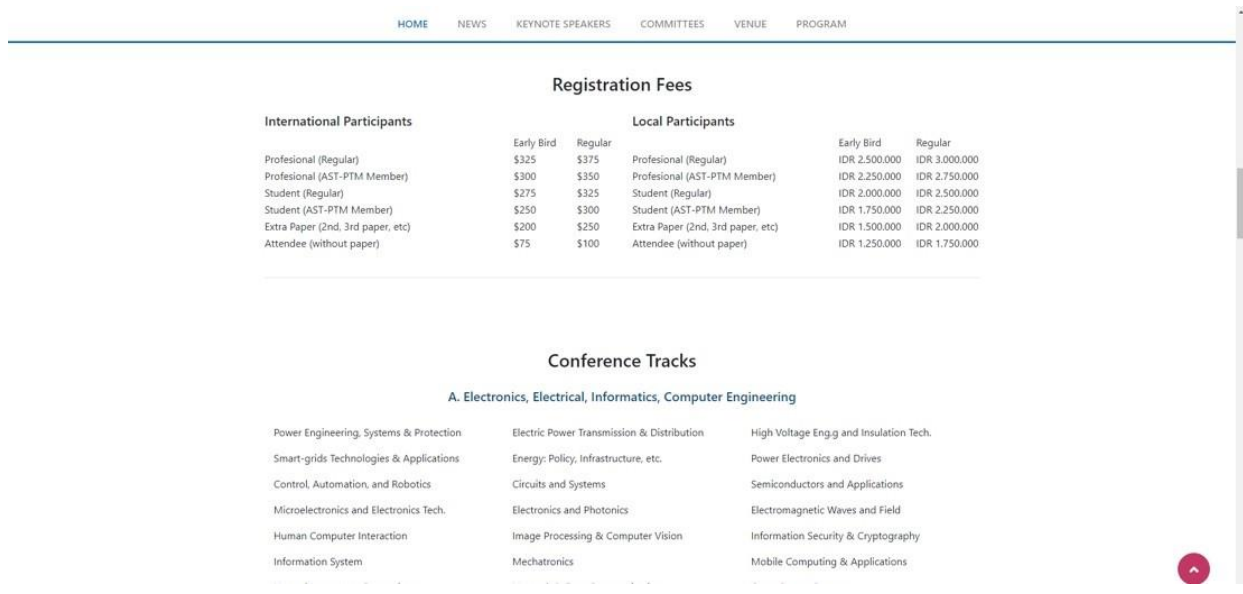

Gambar 6. Implementasi Halaman Home 


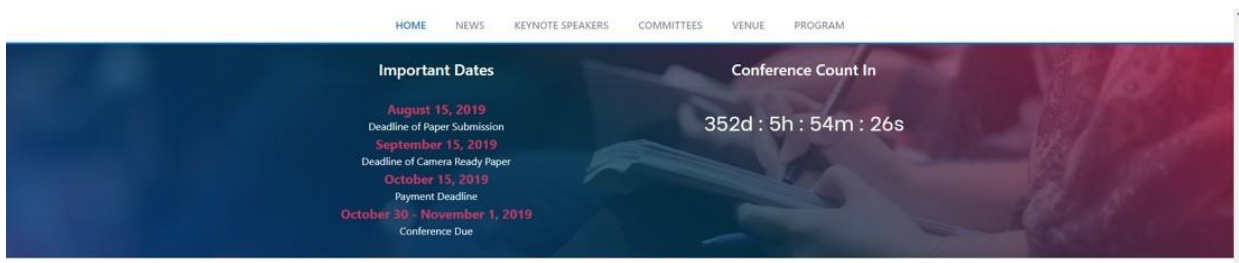

Venue

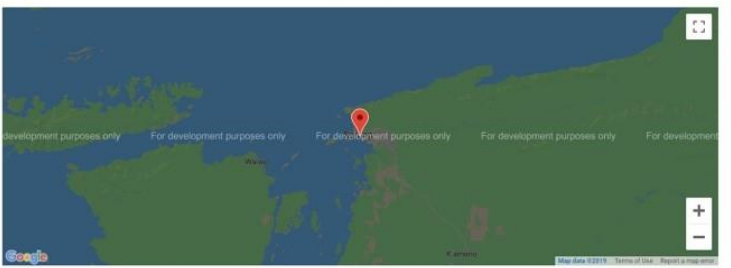

Gambar 7. Implementasi Halaman Home

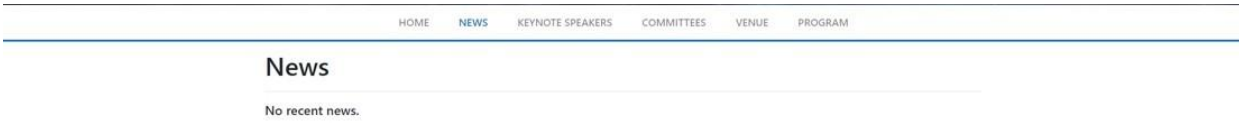

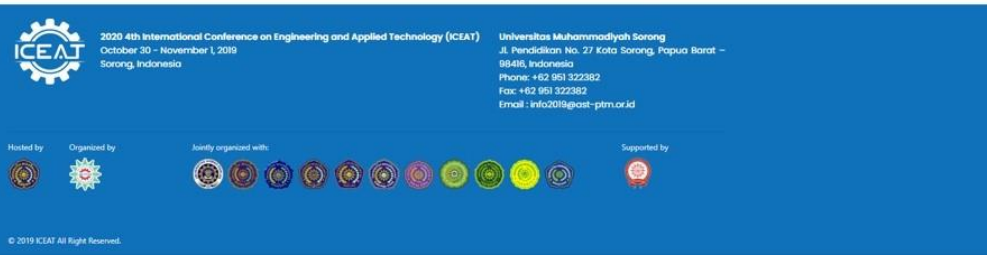

Gambar 8. Implementasi Halaman News

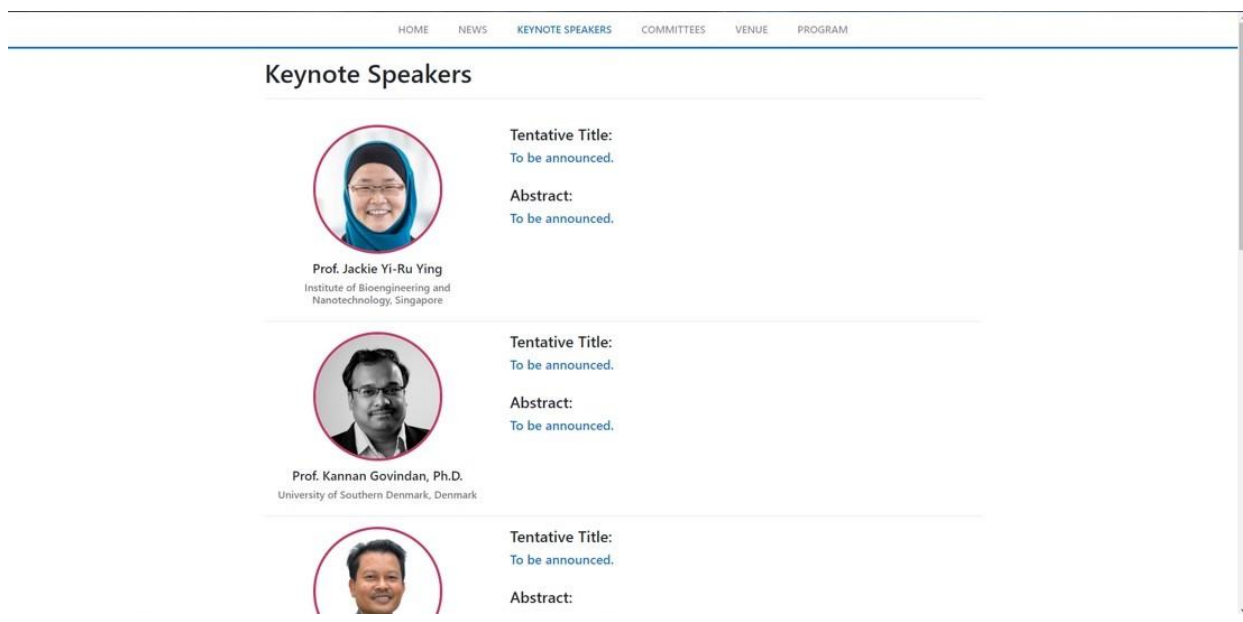

Gambar 9. Implementasi Halaman Keynote Speakers 


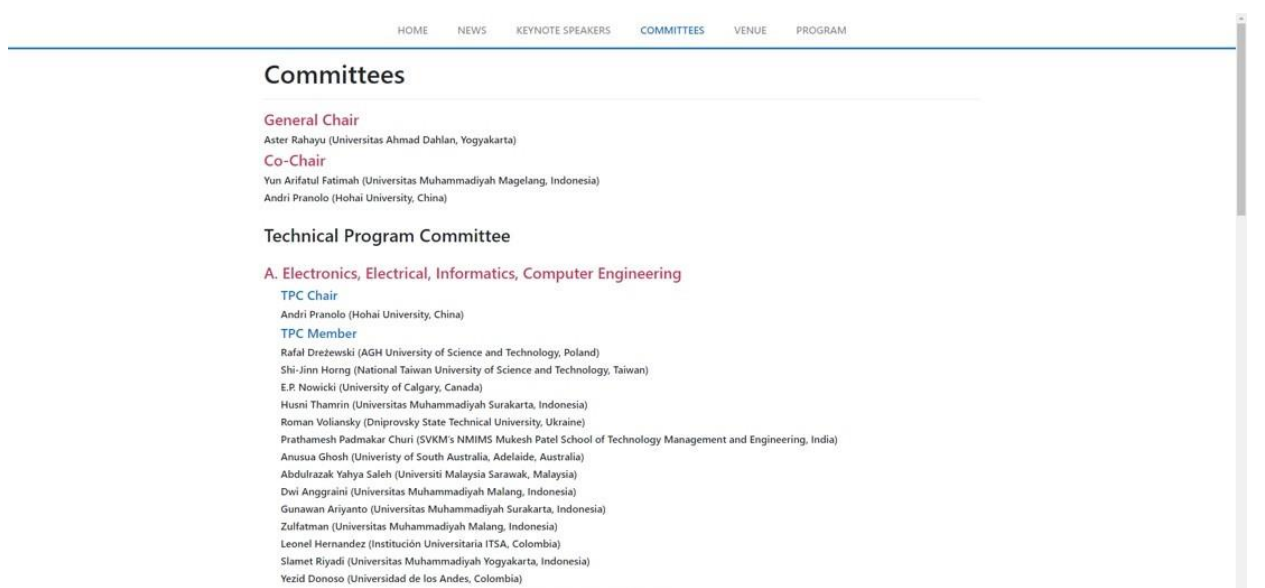

Gambar 10. Implementasi Halaman Committees

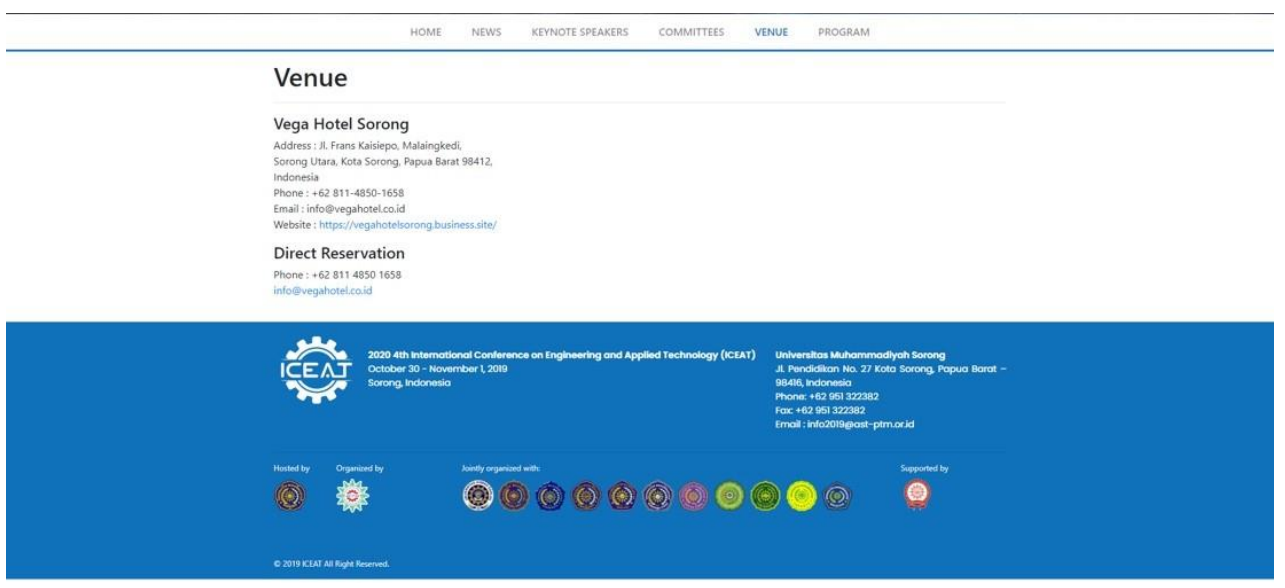

Gambar 11. Implementasi Halaman Venue

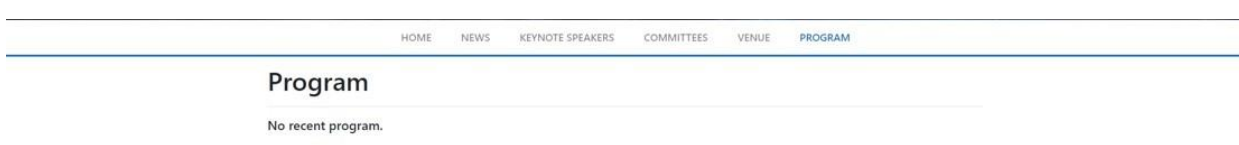

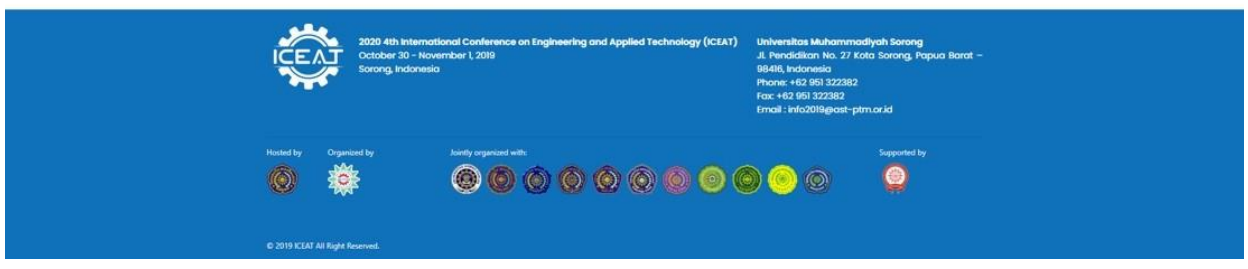

Gambar 12. Implementasi Halaman Program 


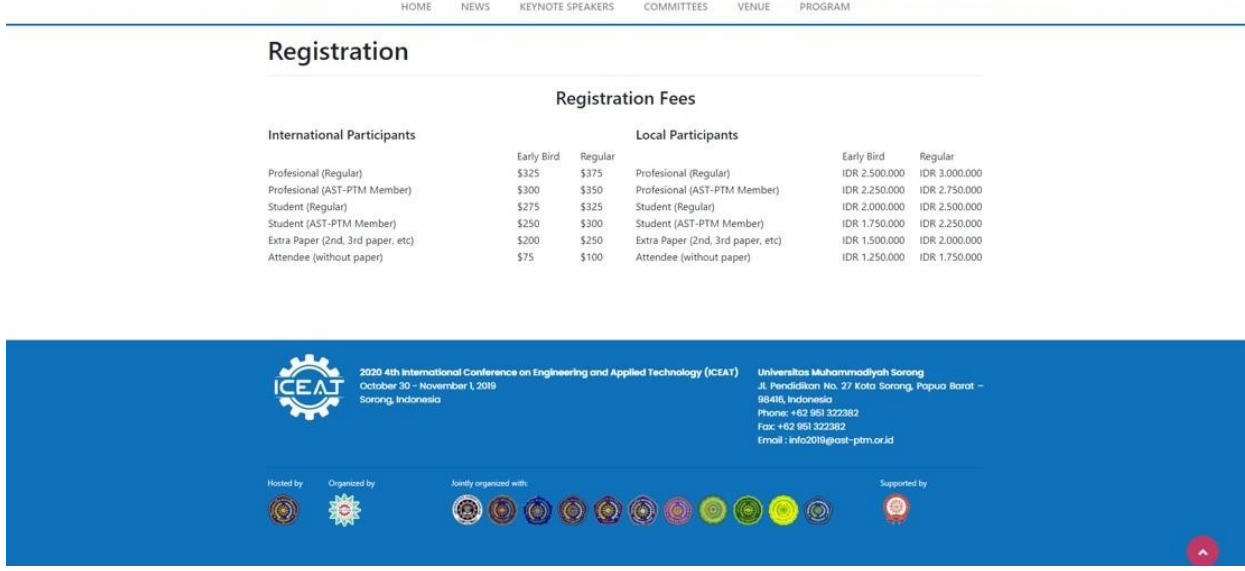

Gambar 13. Implementasi Halaman Registrasi

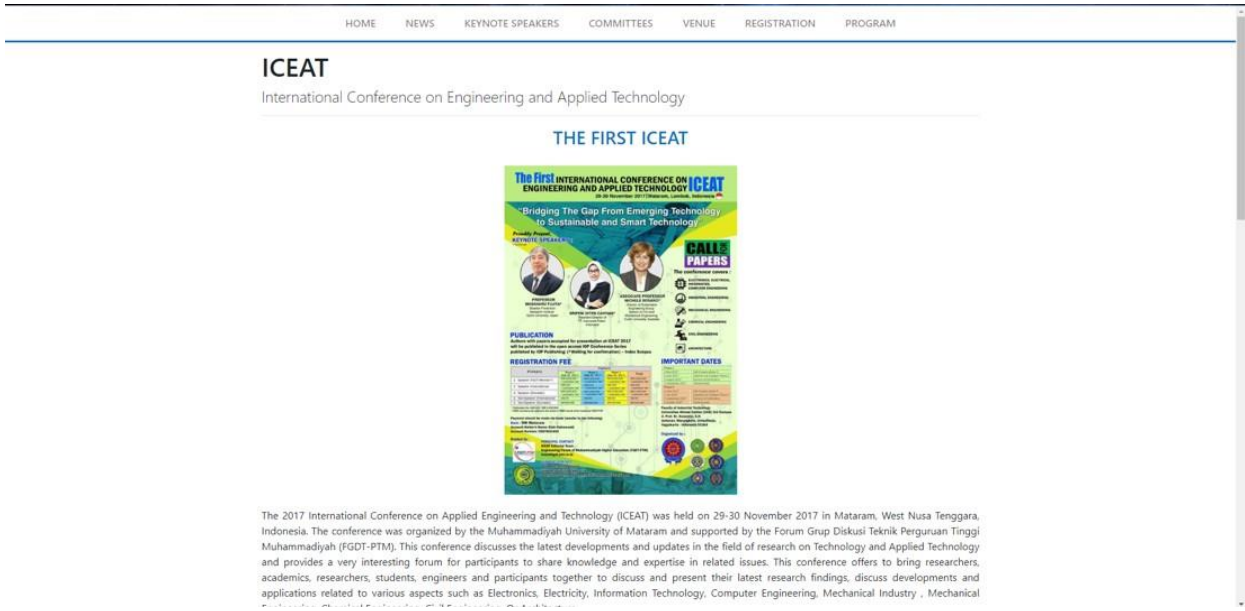

Gambar 14. Implementasi Halaman About

\section{Pengujian Sistem}

\section{- $\quad$ Alpha Test}

Alpha Test adalah salah satu strategi pengujian perangkat lunak yang paling umum digunakan dalam pengembangan perangkat lunak, hal ini khusus digunakan oleh organisasi pengembangan produk dengan tujuan agar sistem yang dikembangkan terhindar dari cacat atau kegagalan penggunaan.

Dengan google form penguji akan diminta membuka alamat website yang akan di test kemudian akan diberika pertanyaan terbuka mengenai website tersebut. Pertanyaan terbuka adalah dengan mengajukan pertanyaan yang terbuka. Ini untuk mengetahui tentang aplikasi yang dibangun telah mampu menampilkan informasi sesuai dengan keadaan yang ada. Berikut rincian hasil hasilnya pada Tabel 2.

Tabel 2. Pengujian Alpha Test

\begin{tabular}{llcc}
\hline No & \multicolumn{1}{c}{ Pertanyaan } & Ya & Tidak \\
\hline 1. & $\begin{array}{l}\text { Apakah saat membuka link website langsung diarahkan ke } \\
\text { laman home? }\end{array}$ & 20 & -
\end{tabular}

Visualisasi Informasi Website International Conference Berdasarkan Web-Quality Framework Pagistu, Azhari, Aktawan 
2. Apakah ketika mengklik menu navigasi langsugn diarahkan $\quad \begin{array}{lll}18 & 2\end{array}$ ke halaman yang tertera di menu navigasi?

3. Di halaman home terdapat beberapa tombol yaitu Submission, Register, dan Publication \& Etics. Apakah ketika mengklik tombol Submission akan diarahkan ke halaman easychair.org?

4. Apakah ketika mengklik tombol Register akan diarahkan ke $\quad 19 \quad 1$ halaman registrasi?

5. Apakah ketika mengklik tombol Publications \& Etics akan $17 \quad 3$ diarahkan ke halaman penjelasan Publications \& Etics?

\section{Total}

Dari pengujian dengan metode Alpha Test dihasilkan 92\% responden menjawab Ya bahwa fungsi yang dibuat sudah berjalan dengan baik, dan sebanyak 8\% menjawab Tidak. Dapat disimpulkan hasil pengujian diperoleh bahwa aplikasi yang telah dibangun sudah sesuai dengan kebutuhan informasi yang ada.

- $\quad$ Software Usability Scale (SUS)

Diberikan kuesioner dengan 10 pertanyaan dalam bentuk google form dan diberikan 5 pilihan jawaban. Mulai dari sangat tidak setuju, tidak setuju, ragu - ragu, setuju, dan sangat setuju. Skor masing - masing mulai dari 1 - 5 . Pilihan jawaban dan skornya dapat dilihat pada Tabel 3.

Tabel 3. Pilihan Jawaban dan Skor

\begin{tabular}{lc}
\hline \multicolumn{1}{c}{ Jawaban } & Skor \\
\hline Sangat tidak setuju & 1 \\
\hline Tidak setuju & 2 \\
\hline Ragu - ragu & 3 \\
\hline Setuju & 4 \\
\hline Sangat setuju & 5
\end{tabular}

Berikut 10 pertanyaan yang diberikan:

1. Saya berpikir akan menggunakan sistem ini lagi

2. Saya merasa sistem ini rumit untuk digunakan

3. Saya merasa sistem ini mudah digunakan

4. Saya membutuhkan bantuan dari orang lain atau teknisi dalam menggunakan sistem ini

5. Saya merasa fitur - fitur sistem ini berjalan dengan semestinya

6. Saya merasa ada banyak hal yang tidak konsisten (tidak serasi pada sistem ini)

7. Saya merasa orang lain akan memahami cara menggunakan sistem ini dengan cepat 
8. Saya merasa sistem ini membingungkan

9. Saya merasa tidak ada hambatan dalam menggunakan sistem ini

10. Saya perlu membiasakan diri terlebih dahulu sebelum menggunakan sistem ini

Dari pertanyaan tersebut diperoleh data hasil pengujian oleh 17 penguji dapat dilihat di Tabel 4.

Tabel 4. Data Hasil Pengujian

\begin{tabular}{cccccccccccc}
\hline No & $\begin{array}{c}\text { Responden } \\
\text { (Resp.) }\end{array}$ & Q1 & Q2 & Q3 & Q4 & Q5 & Q6 & Q7 & Q8 & Q9 & Q10 \\
\hline 1. & Resp. 1 & 4 & 2 & 4 & 2 & 5 & 2 & 4 & 2 & 4 & 3 \\
\hline 2. & Resp. 2 & 4 & 2 & 4 & 2 & 5 & 2 & 4 & 2 & 4 & 3 \\
\hline 3. & Resp. 3 & 4 & 2 & 4 & 2 & 3 & 2 & 4 & 2 & 4 & 3 \\
\hline 4. & Resp. 4 & 4 & 2 & 4 & 2 & 3 & 2 & 4 & 2 & 4 & 3 \\
\hline 5. & Resp. 5 & 4 & 2 & 4 & 2 & 4 & 2 & 4 & 2 & 4 & 3 \\
\hline 6. & Resp. 6 & 4 & 2 & 4 & 2 & 4 & 2 & 4 & 2 & 4 & 3 \\
\hline 7. & Resp. 7 & 4 & 2 & 4 & 2 & 4 & 2 & 4 & 2 & 4 & 3 \\
\hline 8. & Resp. 8 & 4 & 2 & 4 & 2 & 4 & 2 & 4 & 2 & 4 & 3 \\
\hline 9. & Resp. 9 & 4 & 2 & 4 & 2 & 4 & 2 & 4 & 2 & 4 & 2 \\
\hline 10. & Resp. 10 & 4 & 2 & 4 & 2 & 4 & 2 & 4 & 2 & 4 & 2 \\
\hline 11. & Resp. 11 & 4 & 2 & 4 & 2 & 4 & 2 & 4 & 2 & 4 & 2 \\
\hline 12. & Resp. 12 & 4 & 2 & 4 & 2 & 4 & 2 & 4 & 2 & 4 & 4 \\
\hline 13. & Resp. 13 & 4 & 2 & 4 & 2 & 4 & 2 & 4 & 2 & 4 & 2 \\
\hline 14. & Resp. 14 & 4 & 2 & 4 & 2 & 4 & 2 & 4 & 2 & 4 & 3 \\
\hline 15. & Resp. 15 & 4 & 2 & 4 & 2 & 4 & 2 & 4 & 2 & 4 & 3 \\
\hline 16. & Resp. 16 & 4 & 2 & 4 & 2 & 4 & 2 & 4 & 2 & 4 & 3 \\
\hline 17. & Resp. 17 & 4 & 2 & 4 & 2 & 4 & 2 & 4 & 2 & 4 & 3 \\
\hline
\end{tabular}

Setelah melakukan pengumpulan data dari responden, kemudian data akan dihitung. Ada beberapa aturan dalam menghitung skor pada kuesionernya:

- Setiap pertanyaan bernomor ganjil, skor setiap pertanyaan yang didapat dari skor pengguna akan dikurangi 1.

- Setiap pertanyaan bernomor genap, skor didapat dari nilai 5 dikurangi skor pertanyaan yang didapat dari responden.

- Skor SUS didapat dari hasil penjumlahan skor setiap pertanyaan yang kemudian dikali 2,5.

Aturan perhitungan skor berlaku untuk 1 responden. Untuk perhitungan selanjutnya, skor SUS dari masing - masing responden dicari skor rata ratanya dengan menjumlahkan semua skor dan dibagi dengan jumlah responden. Data hasil hitung SUS dapat dilihat pada Tabel 5.

Tabel 5 Skor Akhir Data

\begin{tabular}{ccccccccccccc}
$\begin{array}{c}\text { Responden } \\
\text { (Resp.) }\end{array}$ & Q1 & Q2 & Q3 & Q4 & Q5 & Q6 & Q7 & Q8 & Q9 & Q10 & Jumlah & $\begin{array}{c}\text { Nilai } \\
\text { (Jumlah } \\
\text { x 2,5) }\end{array}$ \\
\hline
\end{tabular}

$\begin{array}{lllllllllllll}\text { Resp. } 1 & 3 & 3 & 3 & 3 & 4 & 3 & 3 & 3 & 3 & 2 & 30 & 75\end{array}$




\begin{tabular}{lllllllllllll}
\hline Resp. 2 & 3 & 3 & 3 & 3 & 4 & 3 & 3 & 3 & 3 & 2 & 30 & 75 \\
\hline Resp. 3 & 3 & 3 & 3 & 3 & 2 & 3 & 3 & 3 & 3 & 2 & 28 & 70 \\
\hline Resp. 4 & 3 & 3 & 3 & 3 & 2 & 3 & 3 & 3 & 3 & 2 & 28 & 70 \\
\hline Resp. 5 & 3 & 3 & 3 & 3 & 3 & 3 & 3 & 3 & 3 & 2 & 29 & 73 \\
\hline Resp. 6 & 3 & 3 & 3 & 3 & 3 & 3 & 3 & 3 & 3 & 2 & 29 & 73 \\
\hline Resp. 7 & 3 & 3 & 3 & 3 & 3 & 3 & 3 & 3 & 3 & 2 & 29 & 73 \\
\hline Resp. 8 & 3 & 3 & 3 & 3 & 3 & 3 & 3 & 3 & 3 & 2 & 29 & 73 \\
\hline Resp. 9 & 3 & 3 & 3 & 3 & 3 & 3 & 3 & 3 & 3 & 3 & 30 & 75 \\
\hline Resp. 10 & 3 & 3 & 3 & 3 & 3 & 3 & 3 & 3 & 3 & 3 & 30 & 75 \\
\hline Resp. 11 & 3 & 3 & 3 & 3 & 3 & 3 & 3 & 3 & 3 & 3 & 30 & 75 \\
\hline Resp. 12 & 3 & 3 & 3 & 3 & 3 & 3 & 3 & 3 & 3 & 1 & 28 & 73 \\
\hline Resp. 13 & 3 & 3 & 3 & 3 & 3 & 3 & 3 & 3 & 3 & 3 & 30 & 75 \\
\hline Resp. 14 & 3 & 3 & 3 & 3 & 3 & 3 & 3 & 3 & 3 & 2 & 29 & 73 \\
\hline Resp. 15 & 3 & 3 & 3 & 3 & 3 & 3 & 3 & 3 & 3 & 2 & 29 & 73 \\
\hline Resp. 16 & 3 & 3 & 3 & 3 & 3 & 3 & 3 & 3 & 3 & 2 & 29 & 73 \\
\hline Resp. 17 & 3 & 3 & 3 & 3 & 3 & 3 & 3 & 3 & 3 & 2 & 29 & 73 \\
\hline
\end{tabular}

Berdasarkan skor akhir rata - rata dari hasil pengujian diperoleh nilai 73 dimana skor tersebut melebihi skor rata - rata SUS yaitu 68 dan masuk dalam kategori layak.

- $\quad$ User Acceptable Test (UAT)

Pengujian dengan UAT dilakukan dengan mengajukan beberapa pertanyaan terhadap pengguna, pengujian ini melibatkan 20 pengguna. Hasil user acceptance test dinilai dari 5 kategori, yaitu SS (Sangat Sesuai), S (Sesuai), KS (Kurang Sesuai), TS (Tidak Sesuai) dan TJ (Tidak Jawab). Berikut rincian hasilnya pada Tabel 6. Data hasil perhitungan UAT yang telah dilakukan ditunjukkan pada Gambar 15.

Tabel 6. Pertanyaan Pengujian UAT

\section{No}

\section{Pertanyaan}

1. Apakah tampilan website ICEAT menarik?

2. Apakah menu - menu website mudah dipahami?

3. Apakah tombol - tombol pada website mudah dipahami?

4. Apakah foto di gallery pada halaman home menarik?

5. Dengan informasi yang ada, apakah anda memahami cara submit paper di website tersebut?

6. Apakah informasi registrasi dan pembayaran mudah dipahami?

7. Apakah adanya penjelasan mengenai ICEAT membantu anda memahami isi conference? 
8. Apakah website ini membantu anda menemukan informasi yang dibutuhkan mengenai conference?

9. Apakah website ICEAT ini dapat dijadikan media bantu penyebaran informasi mengenai kegiatan ICEAT yang akan datang?

10. Apakah website 2020 4th ICEAT ini sudah cukup baik?

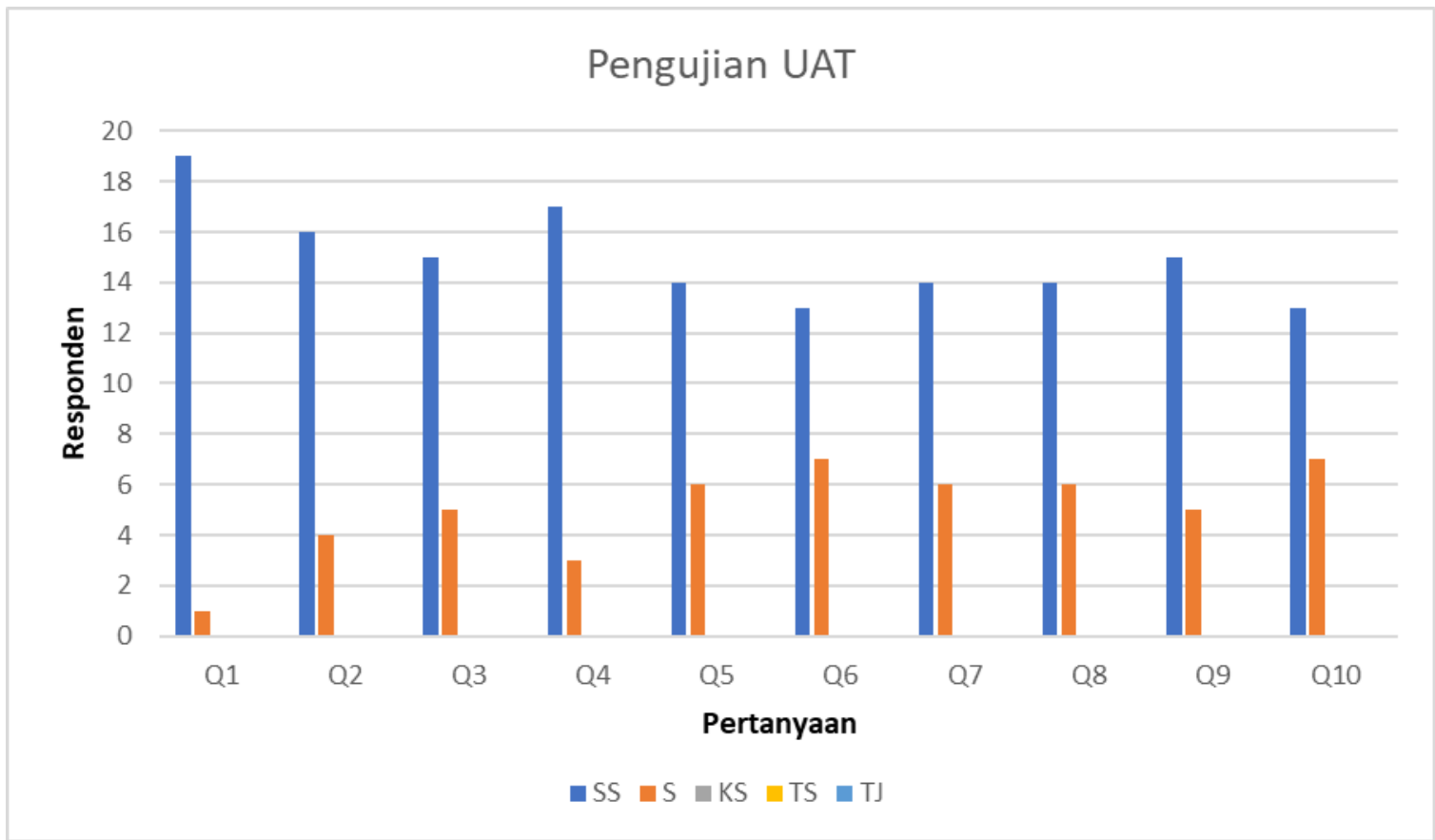

Gambar 15. Pengujian UAT

Dari pengujian dengan metode UAT pada Gambar 15 disimpulkan bahwa 75\% pengguna menyatakan sangat setuju bahwa interface yang dibuat sesuai dengan keinginan, sebanyak $24 \%$ menyatakan setuju dan $1 \%$ menyatakan tidak setuju.

- $\quad$ User Experience Questionnaire (UEQ)

Dilakukan pengujian User Experience (UX) dengan menggunakan kuesioner UEQ. Pengujian ini dilakukan pada 17 responden. Data yang diperoleh dari kuesioner UEQ kemudian dihitung sesuai dengan prosedur dalam analisis data UEQ. Data hasil perhitungan UEQ yang telah dilakukan ditunjukkan pada Tabel 7 .

Tabel 7 Hasil Perhitungan UEQ

\begin{tabular}{cc}
\hline Skala & Nilai \\
\hline Daya tarik & 1,38 \\
\hline Kejelasan & 1,41 \\
\hline Efisiensi & 1,53 \\
\hline Ketepatan & 1,22 \\
\hline
\end{tabular}

Visualisasi Informasi Website International Conference Berdasarkan Web-Quality Framework Pagistu, Azhari, Aktawan 


\begin{tabular}{cc}
\hline Stimulasi & 1,31 \\
\hline Kebaruan & 1,06 \\
\hline
\end{tabular}

UEQ memiliki enam skala penilaian, yaitu daya tarik, kejelasan efisiensi, ketepatan, stimulasi, dan kebaruan. Keseluruhan hasil pengujian UX mendapatkan penilaian yang masuk ke dalam kategori "baik", seperti ditunjukkan pada Gambar 16.

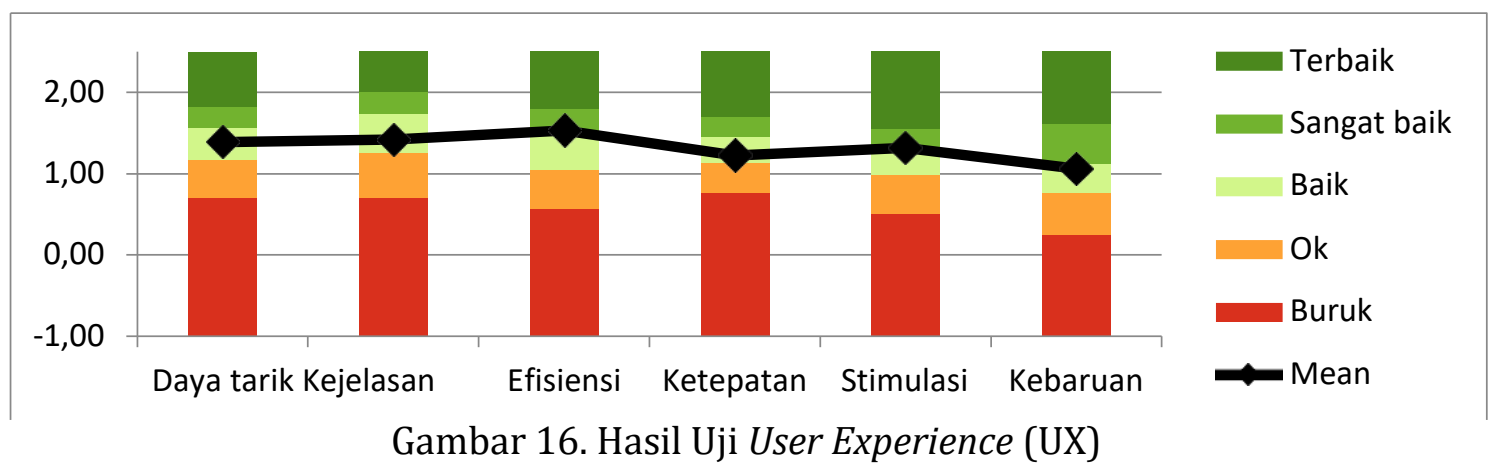

\section{KESIMPULAN}

Dapat disimpulkan bahwa penelitian ini telah mengembangkan sistem informasi konferensi internasional berbasis website dengan mengimplementasikannya pada website 2020 4th International Conference on Engineering and Applied Technology (ICEAT) dengan menggunakan metode pengembangan System Development Life Cycle (SDLC) dan telah diuji menggunakan metode pengujian Alpha Test, Software Usability Test (SUS), dan User Acceptance Test (UAT). Berdasarkan pengujian sistem tersebut diperoleh hasil, bahwa semua fungsi dalam sistem ini sudah bekerja dengan baik ditunjukkan dari hasil pengujian alpha test sebesar 92\%, dapat menampilkan informasi yang sesuai ditunjukkan dari hasil pengujian SUS sebesar 73\%, dapat diterima masyarakat dan layak ditunjukkan dari hasil pengujian UAT sebesar $75 \%$, mampu memenuhi standar penilaian UX dalam kategori "baik" dengan skor pada aspek daya tarik 1,38, kejelasan 1,41, efisiensi 1,53, ketepatan 1,22, stimulasi 1,31, kebaruan 1,06.

\section{DAFTAR PUSTAKA}

[1] B. Wicaksono and A. Susanto, "Evaluasi Kualitas Layanan Website Pusdiklat BPK RI Menggunakan Metode Webqual Modifikasian dan Importance Performance Analysis," J. Nas. Tek. Elektro Dan Teknol. Inf., vol. 2, no. 2, p. 8, 2013, doi: http://dx.doi.org/10.22146/jnteti.v2i2.50.

[2] H. Yuliansyah and I. K. Hildayanti, "Sistem Informasi Farmasi Berbasis Web Mobile Dengan Fitur Deteksi Kesalahan Obat Dalam Penjualan Obat Peracikan," Mob. Forensics, vol. 1, no. 1, p. 41, Sep. 2019, doi: 10.12928/mf.v1i1.645.

[3] M. Mardhia, A. Azhari, and A. Ardiansyah, "Information Visualization of Lesson Study Activity," J. Ilm. Tek. Elektro Komput. Dan Inform., vol. 3, no. 2, p. 141, Jan. 2018, doi: 10.26555/jiteki.v3i2.8546.

[4] A. Azhari, "Pengolahan Data Spasial Epidemologi Leptospirosis ( Studi Kasus Di Kabupaten Kulonprogo )," Universitas Islam Indonesia, Yogyakarta, 2011. 
[5] S. J. A. N. B. S. Mohamad, D. Asirvatham, and H. H. M. Khalid, "Quality Framework for Assessment of Multimedia Learning Materials Version 1.0," Procedia-Soc. Behav. Sci., vol. 67, no. November 2011, pp. 571-579, 2012, doi: 10.1016/j.sbspro.2012.11.362.

[6] B. A. B. Ii and T. Informasi, "Pengertian TIK," pp. 8-29, 2011.

[7] L. Fernando, N. Safriadi, and R. D. Nyoto, "Rancang Bangun Sistem Informasi Konferensi Nasional Aptikom Provinsi Kalimantan Barat Berbasis Web," J. Sist. Dan Teknol. Inf. JUSTIN, vol. 6, no. 3, p. 107, 2018, doi: 10.26418/justin.v6i3.24856.

[8] I. G. S. Widharma, "Perancangan Simulasi Sistem Pendaftaran Kursus Berbasis Web Dengan Metode Sdlc," Matrix J. Manaj. Teknol. Dan Inform., vol. 7, no. 2, p. 38, 2017, doi: 10.31940/matrix.v7i2.527.

[9] E. Usability et al., “1. 240,” pp. 240-245, 2017.

[10] A. W. Soejono, A. Setyanto, A. F. Sofyan, and W. Anova, "Evaluasi Usability Website UNRIYO Menggunakan S ystem Usability Scale ( Studi Kasus : Website UNRIYO )," J. Teknol. Inf., vol. XIII, no. 1, pp. 29-37, 2018.

[11] F. F. Laksana and S. Suyoto, "Pengukuran Kualitas Ux Website Menggunakan Sus," Comput. Eng. Sci. Syst. J., vol. 4, no. 2, p. 138, 2019, doi: 10.24114/cess.v4i2.12928.

[12] I. P. Lunak, "Bab V Implementasi Dan Pengujian,” no. 850, pp. 1-15, 1900.

[13] E. Susilo, F. D. Wijaya, and R. Hartanto, "Perancangan dan Evaluasi User Interface Aplikasi Smart Grid Berbasis Mobile Application," J. Nas. Tek. Elektro Dan Teknol. Inf. JNTETI, vol. 7, no. 2, pp. 150-157, 2018, doi: 10.22146/jnteti.v7i2.416.

[14] A. Luthfi, T. Adinegoro, R. I. Rokhmawati, and H. M. Az-zahra, "Analisis Pengalaman Pengguna pada Website E-commerce Dengan Menggunakan Usability Testing dan User Experience Questionnaire (UEQ) (Studi pada Lazada.co.id, Blibli.com dan JD. id)," J. Pengemb. Teknol. Inf. Dan Ilmu Komput. J-PTIIK Univ. Brawijaya, vol. 2, no. 11, 2018. 